\title{
Densification and Microstructure of Fluorapatite Sintered with Alkaline and Alkaline-Earth Additives
}

\author{
Mustapha Hidouri1,2*, Faycal Ben Tahar ${ }^{1}$, Khaled Bouzouita ${ }^{2}$ \\ ${ }^{1}$ Higher Institute of Applied Sciences, Gabes University, Gabes, Tunisia \\ ${ }^{2}$ RU Catalysis and Materials for Environment and Process, Engineering School, Gabes University, Gabes, Tunisia \\ Email: mustapha.hidouri@issatgb.rnu.tn
}

How to cite this paper: Hidouri, M., Tahar, F.B. and Bouzouita, K. (2018) Densification and Microstructure of Fluorapatite Sintered with Alkaline and Alkaline-Earth Additives. Journal of Materials Science and Chemical Engineering, 6, 52-67. https://doi.org/10.4236/msce.2018.61007

Received: December 10, 2017

Accepted: January 8, 2018

Published: January 11, 2018

Copyright ( 92018 by authors and Scientific Research Publishing Inc. This work is licensed under the Creative Commons Attribution International License (CC BY 4.0).

http://creativecommons.org/licenses/by/4.0/

\section{(c) (i) Open Access}

\begin{abstract}
A study was performed to investigate the effect of some selected sintering additives on the densification and microstructure of fluorapatite (FAp, $\left.\mathrm{Ca}_{10}\left(\mathrm{PO}_{4}\right)_{6} \mathrm{~F}_{2}\right)$. The sintering aids, used for improving the material densification at lower than $1080^{\circ} \mathrm{C}$ temperature, were classified according to their cations as alkaline such as $\mathrm{Li}_{2} \mathrm{CO}_{3}, \mathrm{NaF}, \mathrm{Na}_{2} \mathrm{CO}_{3}, \mathrm{Na}_{3} \mathrm{PO}_{4}, \mathrm{KCl}, \mathrm{K}_{2} \mathrm{CO}_{3}$, and alkaline-earth such as $\mathrm{CaF}_{2}, \mathrm{CaCl}_{2}$ and $\mathrm{MgCl}_{2}$. Amounts of $0.1 ; 1$ and 3 wt\% were vigorously homogenized with FAp powders then the solid mixture was pressurelessly sintered under argon flow with $10^{\circ} \mathrm{C} \cdot \mathrm{min}^{-1}$ heating and cooling speed. The density of each sintered material was determined by calculation of the pellet dimension and weight, the crystalline phases were identified using X-ray diffraction (XRD) and the phase morphology was examined by scanning electron microscopy (SEM). The dependence of densification and microstructure on sintering temperature range $900^{\circ} \mathrm{C}-1000^{\circ} \mathrm{C}$ and amount of sintering aids was studied. It was found that all sintering additives were able to ameliorate the sintrability of the material at temperatures $900^{\circ} \mathrm{C}$ and $1000^{\circ} \mathrm{C}$. Maximums of about $96 \%$ were reached with adequate amounts and sintering temperatures. An exception was found with $\mathrm{KCl}$ which had no effect on the density. The microstructures of sintered specimens strictly follow the densification ratios and the sintering mechanism depended on the melting point of the additive.
\end{abstract}

\section{Keywords}

Fluorapatite, Sintering Additive, Densification, Microstructure 


\section{Introduction}

Thanks to their biocompatibility and bioactivity, hydroxyl and fluoroapatite (HAp, FAp) have spurred extensive attention from researcher. The structure and composition of these materials are close to the mineral part of bone tissue. That's why these materials seem to be good candidates for bone and dental replacement [1] [2] [3] [4] [5]. The two materials make part of the apatite family with a formula $\mathrm{M}_{10}\left(\mathrm{PO}_{4}\right)_{6} \mathrm{Y}_{2}$ (M: metal; $\mathrm{Y}$ : anions) and space group P63/m. Among them, hydroxyapatite $\mathrm{Ca}_{10}\left(\mathrm{PO}_{4}\right)_{6} \mathrm{OH}_{2}$ : HAp has been exhaustively studied and its potentialities as a biomaterial are well defined [6]-[11].

Fluorapatite: FAp, the isotype of HAp, in which fluoride was replaced by the hydroxyl ions, also considered as a component of teeth and known by its resistance to acids from plaque-forming bacteria and high carbohydrate intake [12]. Furthermore, it allows mineralization and demineralization of hard tissues [13]. All these properties and others encouraged several researchers to fabricate porous ceramics and composites of FAp [14] [15] [16] [17] [18], while others have been interested in studying glasses ceramics containing FAp [19] [20]. For our work, we studied the effect of magnesium-calcium substitution on the properties of FAp [21] [22] [23] [24]; we also studied the sintering of the FAp containing magnesium in the presence of additives such as $\mathrm{Li}_{2} \mathrm{CO}_{3}, \mathrm{NaF}, \mathrm{Na}_{2} \mathrm{CO}_{3}, \mathrm{Na}_{3} \mathrm{PO}_{4}$, $\mathrm{KCl}, \mathrm{K}_{2} \mathrm{CO}_{3}, \mathrm{CaF}_{2}, \mathrm{CaCl}_{2}$ and $\mathrm{MgCl}_{2}$ [22]. The purpose of the present study is also to examine the sintering behavior of FAp in the presence of the mentioned sintering additives.

\section{Material and Methods}

FAp was synthesized according to an aqueous precipitation method described elsewhere [21]. The obtained powder, with a $\mathrm{Ca} / \mathrm{P}$ ratio of 1.66 , was calcined at $500^{\circ} \mathrm{C}$ for 1 hour (h) under an Argon flow. The specific surface area designated by SSA and determined by BET method using a Nova 2000 michrometer, of the calcined powder was $24.3 \mathrm{~m}^{2} \cdot \mathrm{g}^{-1}$.

The mixture of Fap and additives in amounts of $0.1,1$ and 3 weight\% (wt\%), respectively ground and homogenized in an agate mortar were uniaxially compacted in a stainless steel mold into pellets $(13 \mathrm{~mm} \times 4 \mathrm{~mm})$ at $100 \mathrm{MPa}$. Then the pellets were sintered, as in the case of the magnesium-substituted FAp [22], under argon flow at $900^{\circ} \mathrm{C}$ and $1000^{\circ} \mathrm{C}$ for $1 \mathrm{~h}$. The heating and cooling rate was of $10^{\circ} \mathrm{C} \mathrm{min}{ }^{-1}$.

The sintered samples were characterized based on relative density, X-ray diffraction analysis using a Philips PW 1710 diffractometer and on microstructural analysis using a scanning electron microscope (PHILIPS XL 30).

\section{Results and Discussions}

\subsection{Sintrability of Fluorapatite}

Figure 1 depicted the grains SSA evolution versus heating temperature of both green and compacted FAp powders. A decrease of the SSA to near $5 \mathrm{~m}^{2} \cdot \mathrm{g}^{-1}$ is obtained when temperature increased up to $1000^{\circ} \mathrm{C}$. This was mainly for green 


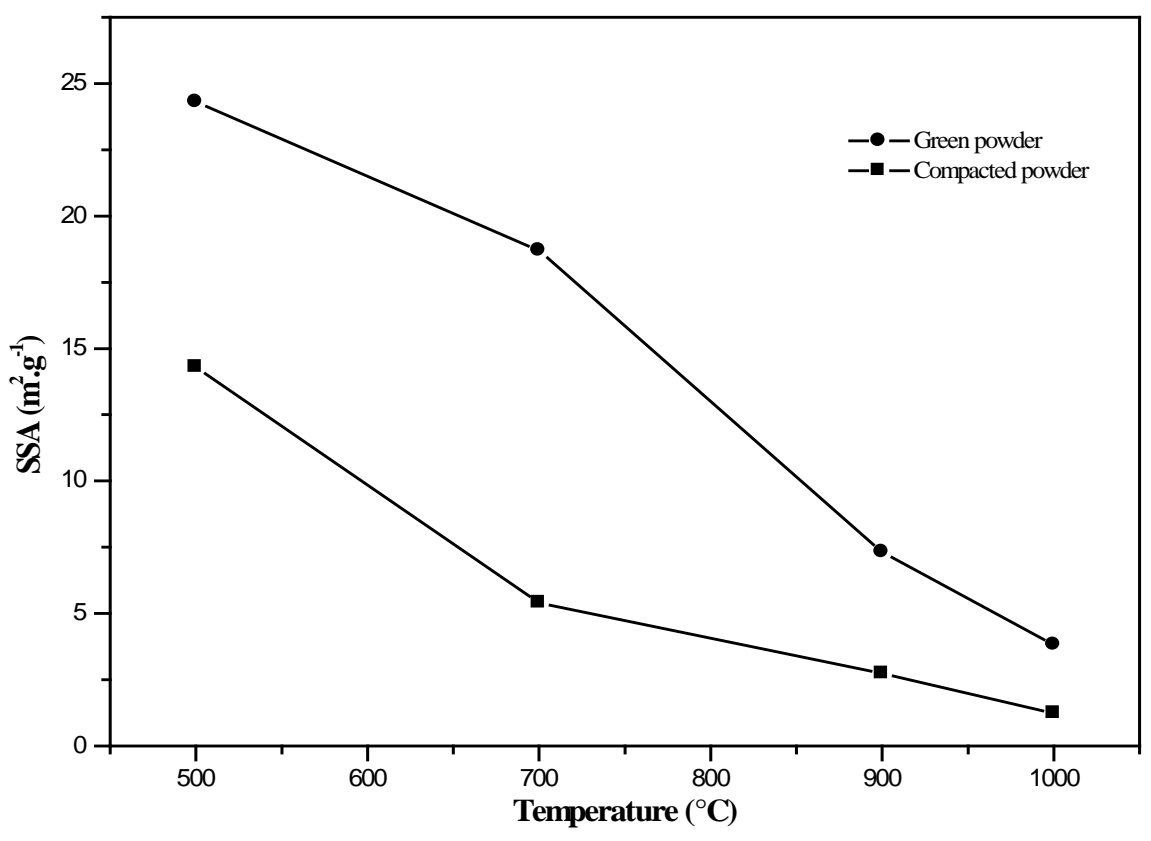

Figure 1. Specific surface area versus temperature for compacted and green powders of FAp.

powders. That means a grain coarsening occurred during heating. This was in competition with the material densification. From these data it appeared that FAp sintering starts from $700^{\circ} \mathrm{C}$ similarly to that of Mg-FAp given by the dialometric analysis [21]. The sintering of FAp without additives at $900^{\circ} \mathrm{C}$ and $1000^{\circ} \mathrm{C}$ for $1 \mathrm{~h}$ led to relative densities of about 0.74 and 0.92 , respectively. Maximum densification of 0.96 was obtained at $1080^{\circ} \mathrm{C}$ with the same duration [25]. According to the density, at $900^{\circ} \mathrm{C}$, the sample was not much sintered. The microstructure was constituted by small particles with an average diameter of 1 $\mu \mathrm{m}$ (Figure 2(a)). At $1000^{\circ} \mathrm{C}$, the sample was better densified, but there were still many pores. The sintering was accompanied by an important coarsening of the grains, but not enough to induce the full densification (Figure 2(b)).

\subsection{Sintering of Fluorapatite with Additives}

The results obtained after one hour of heat treatment (Table 1 and Table 2) show that the efficiency of a given additive depends on its nature, on the quantity used and on the temperature.

\subsubsection{Alkaline Additives}

It appears from Table 1 that these compounds are effective densification additives with the exception of potassium chloride, its use results in practically no improvement in density whatever the content or the temperature employed.

\section{1) Sodium additives}

Three compounds were used: sodium fluoride $(\mathrm{NaF})$, sodium carbonate $\left(\mathrm{Na}_{2} \mathrm{CO}_{3}\right)$ and sodium orthophosphate $\left(\mathrm{Na}_{3} \mathrm{PO}_{4}\right) . \mathrm{Na}_{3} \mathrm{PO}_{4}$ has a melting point above $1000^{\circ} \mathrm{C}\left(1583^{\circ} \mathrm{C}\right)$ while $\mathrm{NaF}$ and $\mathrm{Na}_{2} \mathrm{CO}_{3}$ melt at $858^{\circ} \mathrm{C}$ and $996^{\circ} \mathrm{C}$, 


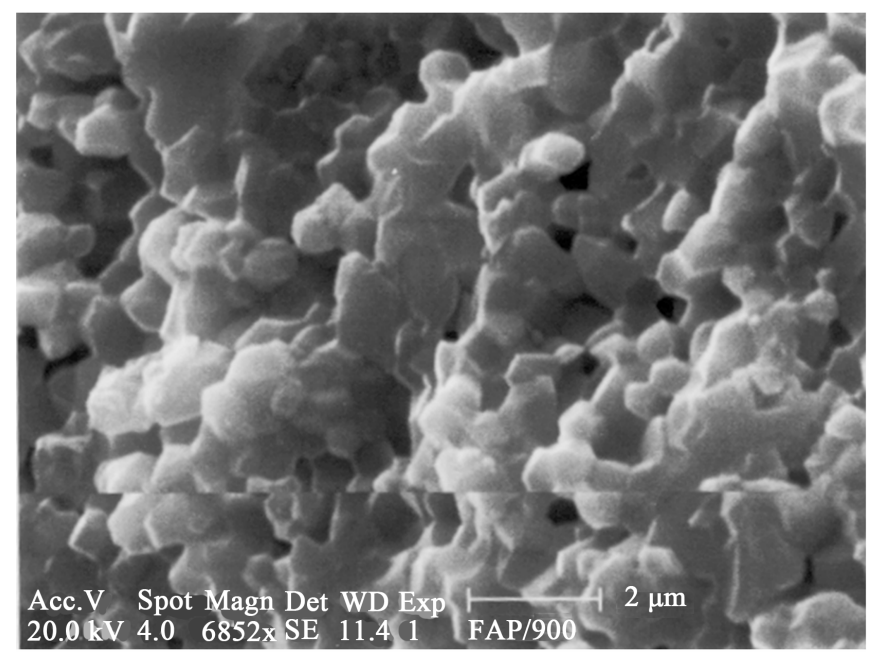

(a)

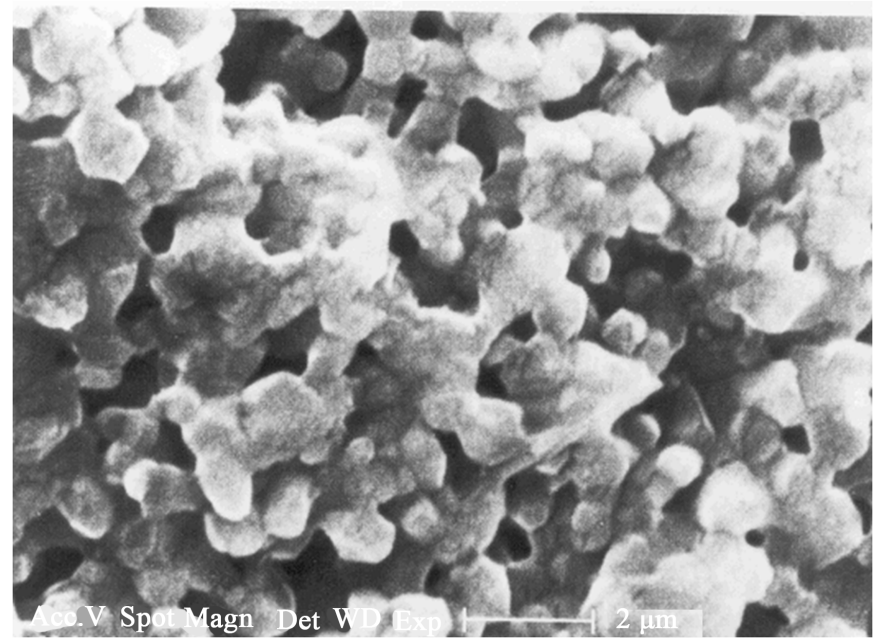

(b)

Figure 2. Scanning electron microscopy of fracture micrographs of sintered FAp. (a) At $900^{\circ} \mathrm{C}$; (b) At $1000^{\circ} \mathrm{C}$.

Table 1. Relative densities obtained for samples sintered with alkaline sintering additives.

\begin{tabular}{ccccc}
\hline Sintering additive & $\mathrm{T}\left({ }^{\circ} \mathrm{C}\right) \mathrm{wt} \%$ & 0.1 & 1 & 3 \\
\hline $\mathrm{Na}_{3} \mathrm{PO}_{4}$ & 900 & 0.83 & 0.86 & 0.82 \\
& 1000 & 0.96 & 0.95 & 0.95 \\
$\mathrm{Na}_{2} \mathrm{CO}_{3}$ & 900 & 0.88 & 0.93 & 0.91 \\
& 1000 & 0.95 & 0.95 & 0.94 \\
$\mathrm{NaF}$ & 900 & 0.90 & 0.88 & 0.81 \\
& 1000 & 0.95 & 0.92 & 0.87 \\
$\mathrm{Li}_{2} \mathrm{CO}_{3}$ & 900 & 0.92 & 0.86 & 0.85 \\
& 1000 & 0.91 & 0.89 & 0.87 \\
$\mathrm{KCl}$ & 900 & 0.64 & 0.62 & 0.6 \\
& 1000 & 0.68 & 0.7 & 0.7 \\
$\mathrm{~K}_{2} \mathrm{CO}_{3}$ & 900 & 0.94 & 0.91 & 0.87 \\
& 1000 & 0.93 & 0.91 & 0.88 \\
\hline
\end{tabular}


respectively. Data show the efficiency of the three additives for the FAp sintering; meanwhile the effect of each additive was tightly related to the temperature and the percentage used. If $\mathrm{Na}_{3} \mathrm{PO}_{4}$ is not efficient at $900^{\circ} \mathrm{C}$ whatever the rate employed at $1000^{\circ} \mathrm{C}$, only $0.1 \mathrm{wt} \%$ is sufficient to improve the sample density, which reaches a maximum of $96 \%$. For $\mathrm{Na}_{2} \mathrm{CO}_{3}, 1 \mathrm{wt} \%$ is necessary to obtain a density of $93 \%$ at $900^{\circ} \mathrm{C}$. However, beyond this value there is a slight decrease in the relative density. At $1000^{\circ} \mathrm{C}$, the relative density is 0.95 when only $0.1 \mathrm{wt} \%$ is used. At both temperatures, $\mathrm{NaF}$ leads to poorer results when the used amount is higher than $0.1 \mathrm{wt} \%$ (Table 1).

The XRD patterns of all the sintered samples revealed besides the FAp the presence of $\beta-\mathrm{NaCa}\left(\mathrm{PO}_{4}\right)$ phase (Figure 3). This phase might be the product of the reaction between the additives and the FAp, according to the chemical equations cited in a previous work [22].

SEM micrographs of the fracture surfaces of samples sintered at $900^{\circ} \mathrm{C}$ and $1000^{\circ} \mathrm{C}$ are shown in Figure 4. Compared to sintered pure FAp (Figure 2), microstructures behavior were completely changed with sodium additives. The sintered samples at $900^{\circ} \mathrm{C}$ showed three different microstructures, highlighting

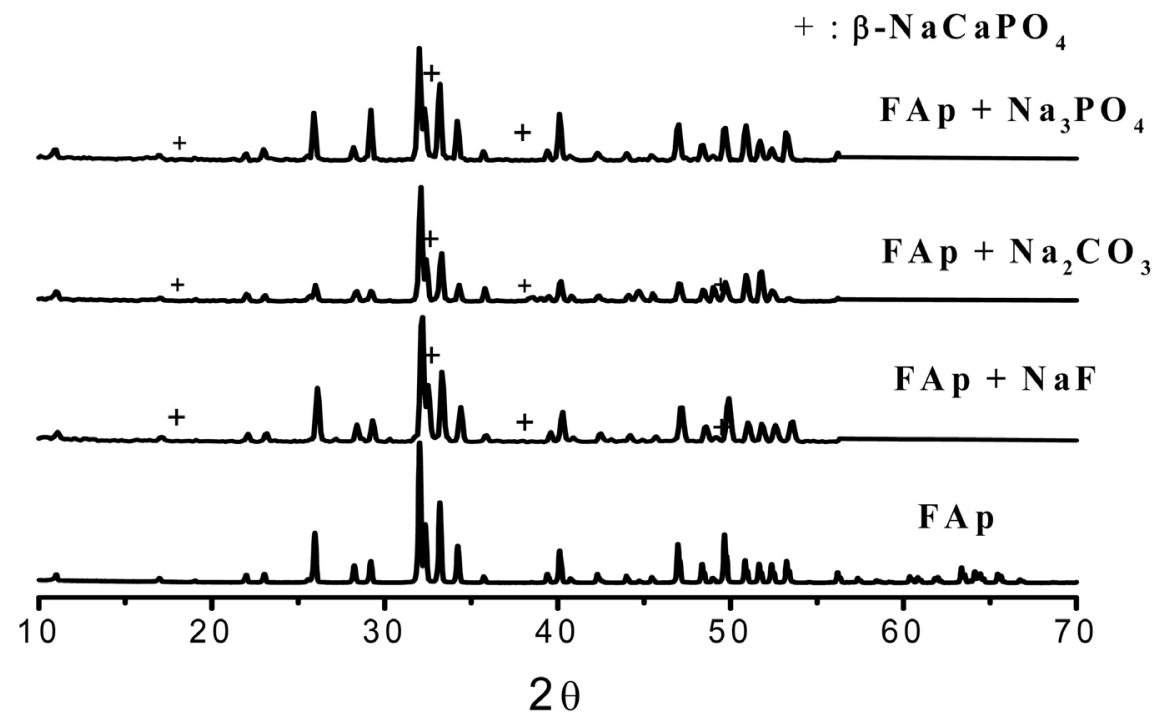

Figure 3. Diffractograms of sintered FAp with sodium sintering additives.

Table 2. Relative densities obtained for samples sintered with alkaline-earth sintering additives.

\begin{tabular}{ccccc}
\hline Sintering additive & $\mathrm{T}\left({ }^{\circ} \mathrm{C}\right) \mathrm{wt} \%$ & 0.1 & 1 & 3 \\
\hline \multirow{2}{*}{$\mathrm{CaCl}_{2}$} & 900 & 0.85 & 0.85 & 0.86 \\
& 1000 & 0.93 & 0.94 & 0.96 \\
$\mathrm{MgCl}_{2}$ & 900 & 0.87 & 0.88 & 0.87 \\
& 1000 & 0.94 & 0.95 & 0.96 \\
$\mathrm{CaF}_{2}$ & 900 & 0.87 & 0.83 & 0.84 \\
& 1000 & 0.96 & 0.95 & 0.94 \\
\hline
\end{tabular}




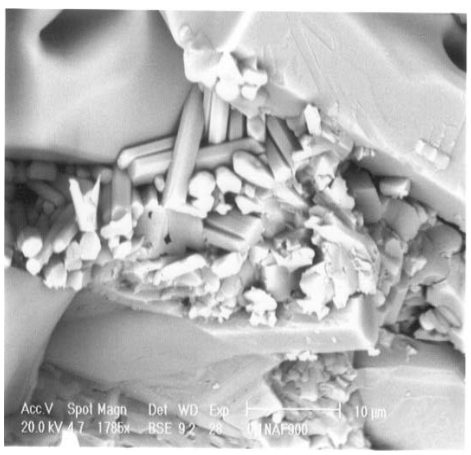

(a)

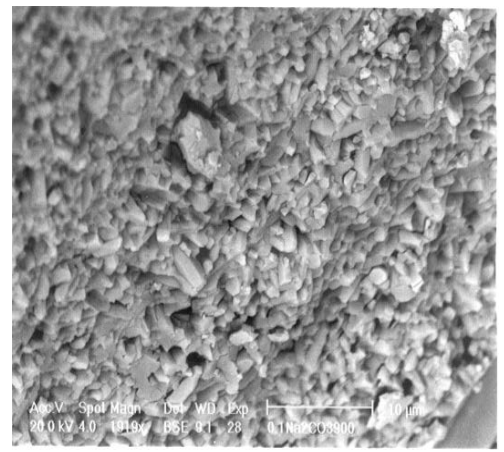

(c)

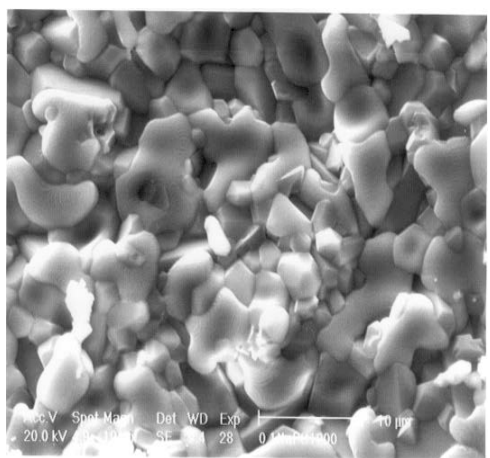

(e)

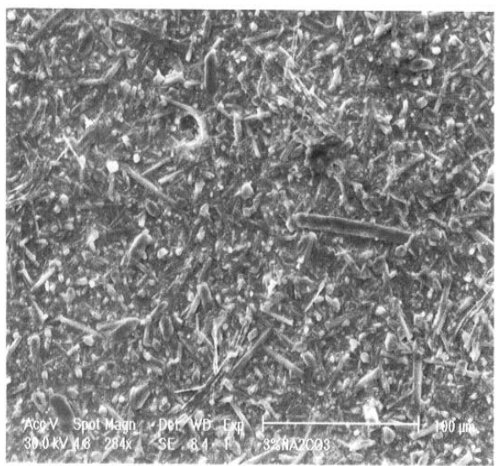

(g)

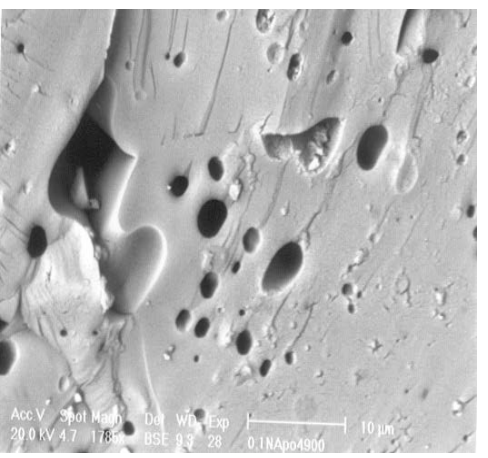

(b)

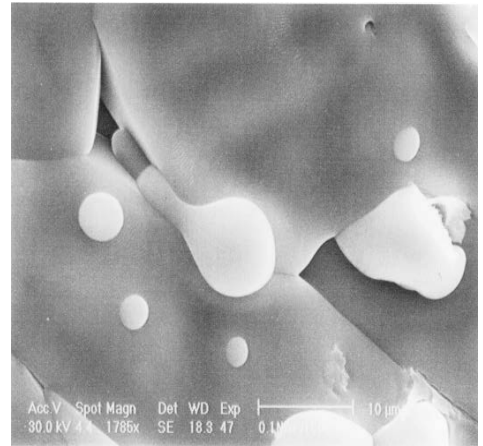

(d)

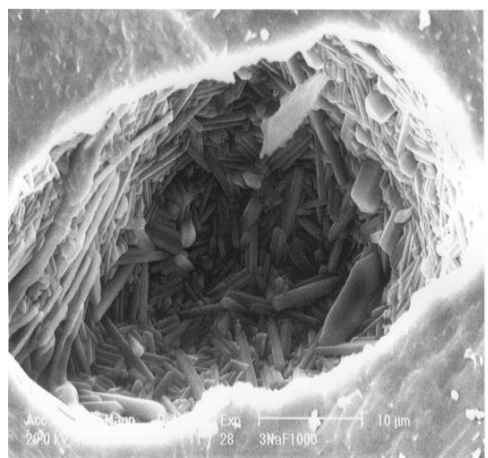

(f)

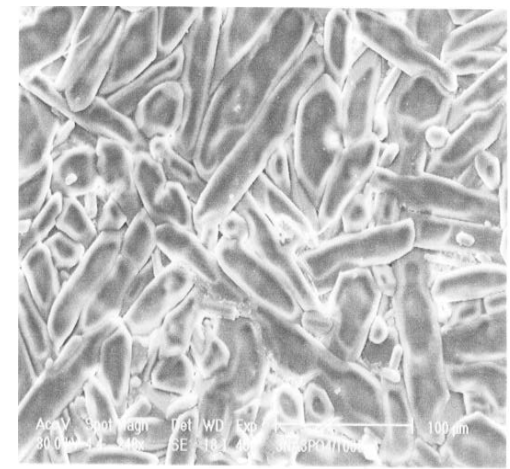

(h)

Figure 4. Scanning electron microscopy fracture micrographs of sintered FAp with sodium sintering additives. At $900^{\circ} \mathrm{C}$ : (a) $0.1 \mathrm{wt} \% \mathrm{NaF}$; (b) $0.1 \mathrm{wt} \% \mathrm{Na}_{2} \mathrm{CO}_{3}$; (c) $0.1 \mathrm{wt} \%$ $\mathrm{Na}_{3} \mathrm{PO}_{4}$. At $1000^{\circ} \mathrm{C}$ : (d) $0.1 \mathrm{wt} \% \mathrm{NaF}$; (e) $0.1 \mathrm{wt} \% \mathrm{Na}_{3} \mathrm{PO}_{4}$; (f) $3 \mathrm{wt} \% \mathrm{NaF}$; (g) $3 \mathrm{wt} \%$ $\mathrm{Na}_{2} \mathrm{CO}_{3}$; (h) 3 wt $\% \mathrm{Na}_{3} \mathrm{PO}_{4}$. 
also the sintering sensitivity to the nature of the anion of the additive compound. At $900^{\circ} \mathrm{C}$, in the presence of $0.1 \mathrm{wt} \%$ of each additives, all the samples presented a relatively high amount of porosity. $\mathrm{NaF}$ led to a microstructure constituted by very small rod-shaped particles inserted between large particles having a polyhedral shape (Figure 4(a)). However, the microstructures obtained with $\mathrm{Na}_{3} \mathrm{PO}_{4}$ (Figure 4(b)) have a transgranular aspect with some cavities at the surface. $\mathrm{Na}_{2} \mathrm{CO}_{3}$ has a homogeneous microstructure formed by very small polyhedral particles having an average diameter of $0.7 \mu \mathrm{m}$ (Figure $4(\mathrm{c})$ ). When temperature increased to $1000^{\circ} \mathrm{C}$, with the added amounts $0.1 \mathrm{wt} \%$, micrographs confirmed the good densification of the material in accordance with given densifications values ( 96\%). In fact, with $\mathrm{NaF}$, a coarsening of grains and reduced porosity are observed. Besides that the secondary phase of $\beta-\mathrm{NaCaPO}_{4}$ was well distinguished. $\mathrm{Na}_{3} \mathrm{PO}_{4}$ induces the formation of polyhedral grains with a variable size ranging from 0.5 to $1 \mu \mathrm{m}$. Some flattened grains are also formed. With $\mathrm{Na}_{2} \mathrm{CO}_{3}$, the porosity is fully reduced and the use of $3 \mathrm{wt} \%$ of additives at $1000^{\circ} \mathrm{C}$ was more efficient with $\mathrm{Na}_{2} \mathrm{CO}_{3}$ and $\mathrm{Na}_{3} \mathrm{PO}_{4}$ compared to $\mathrm{NaF}$. Hence, with $\mathrm{NaF}$, the fracture surface is formed by whole pores containing prismatic crystals (Figure $4(d)$ ) in accordance with obtained densification ratio. Similar prismatic crystals form all the microstructures of samples sintered with $\mathrm{Na}_{3} \mathrm{PO}_{4}$ and $\mathrm{Na}_{2} \mathrm{CO}_{3}$. Meanwhile those with $\mathrm{Na}_{3} \mathrm{PO}_{4}$ are more developed with an average length and width of 3 and $10 \mu \mathrm{m}$ respectively. By contrast, those with $\mathrm{Na}_{2} \mathrm{CO}_{3}$ were less developed. These formed bodies seem to be originating from the elongation of the particles during the dimensionless stage of sintering. These observations are similar to those given in the sintering of magnesium containing FAp or HAp with these additives [22] [26]. Given these facts, sintering with sodium additives occurred in the presence of a liquid phase that of $\mathrm{Na}_{3} \mathrm{PO}_{4}$ resulted from a eutectique between the FAp and the additive as previously indicated [22]. This means that the first step is the grain rearrangment followed by the dissolution-diffusion-reprecipitation leading to a redistribution of the grain and elimination of porosity leading to maximum densification of the material.

\section{2) Addition of $\mathrm{Li}_{2} \mathrm{CO}_{3}$}

So as to examine the effect of $\mathrm{Li}_{2} \mathrm{CO}_{3}$ as a sintering aid on the densification of FAp variable add amount and temperature were utilized. The results given in Table 1 show a significant improvement at $900^{\circ} \mathrm{C}$ and a relative density increase by $18 \%$. However, whatever the quantity used its use at $1000^{\circ} \mathrm{C}$ remains practically without effect on the density. To prevent the effect on densification of the liquid phase relative to the melting point of $\mathrm{Li}_{2} \mathrm{CO}_{3}\left(\mathrm{~T}_{\mathrm{f}}=723\right)$; similarly to Mg-FAp [22], an optimization of the sintering condition of FAp was done by varying the duration and fixing the sintering temperature at $900^{\circ} \mathrm{C}$ and added amount at $0.1 \mathrm{wt} \%$ then $3 \mathrm{wt} \%$. Maximum densities of $92 \%$ and $85 \%$ were reached after 5 minutes, and the longer the duration the less the density. The $\mathrm{XRD}$ patterns revealed as secondary phases $\mathrm{LiF}$ and $\mathrm{CaO}$ (Figure 5). Formed $\mathrm{LiF}$ certainly increased the amount of the existing liquid phase $\left(\mathrm{T}_{\mathrm{f}}=848^{\circ} \mathrm{C}\right)$. 


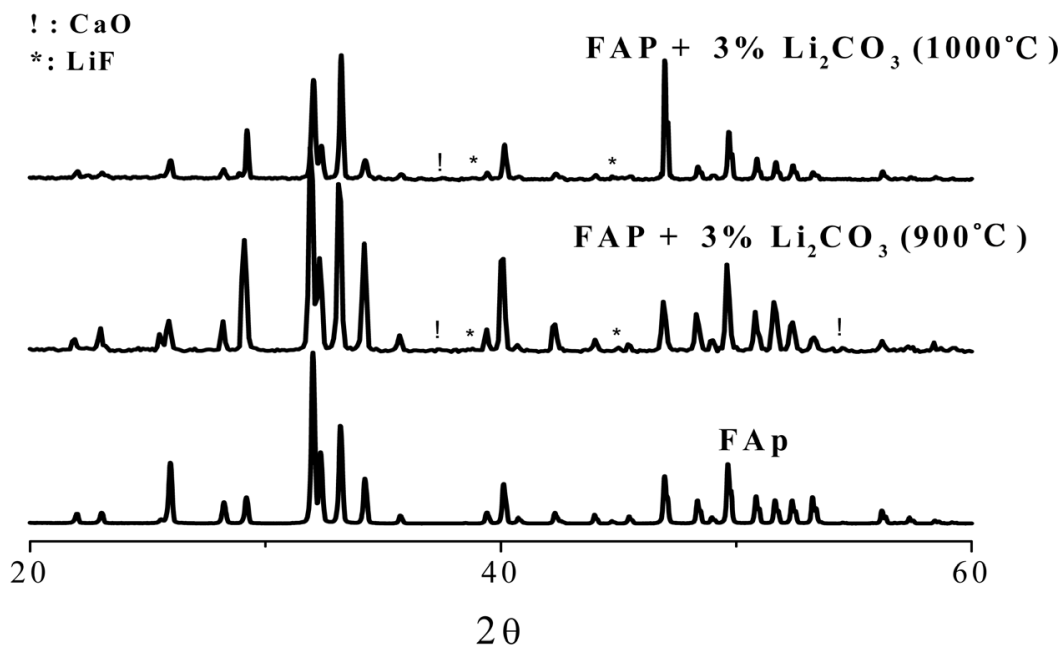

Figure 5. Diffractograms of FAp sintered with $\mathrm{Li}_{2} \mathrm{CO}_{3}$.

SEM observation carried out on fracture of samples sintered at $900^{\circ} \mathrm{C}$ shows that a liquid phase perfectly coats the grains and the microstructure took a transgranular behavior. The numerous existing pores seem to be superficial; the smaller ones correspond to almost filled pores by the liquid furthermore the larger ones correspond to an incompletely filled pores (Figure 6(a)). With the increase of the added amount up to $3 \mathrm{wt} \%$ and temperature up to $1000^{\circ} \mathrm{C}$, the most striking phenomenon is the presence of rod-shaped particles having different sizes and shapes which were not seen with Mg-FAp (Figure 6(b) and Figure 6(c)). The abundant porosity shown in these microstructures explain the low obtained density 0.85 . The densification of the material therefore takes place in two stages. The first is very rapid due to the formed liquid phase, the second generated by the capillary forces which lead to the grains rearrangement. The maximum density (92\%) is reached after only five minutes at $900^{\circ} \mathrm{C}$ in the presence of $0.1 \mathrm{wt} \%$. When the added amount increased, the decrease in the density can be explained by the existence of a closed residual porosity, greater than closed microstructure caused by increased quantity of the liquid phase. During the step of dissolution-reprecipitation, the existence of rod-shaped particles suggests that the grain coarsening may be caused similarly by the volume and surface diffusion. In fact, there is a competition between the liquid and the solid phase diffusion where the liquid phase diffusion is much faster.

\section{3) Potassium additives}

From the results given in Table $1, \mathrm{KCl}$ as a sintering aid hindered the densification of FAp. Ratios obtained in its presence do not exceed $75 \%$, the reason why it was set apart from the used additives list. Similar behavior was noticed with magnesium substituted FAp [22]. This may be caused by the presence of the secondary phase $\mathrm{KCaPO}_{4}$ detected by XRD and its limiting effect on the densification of the FAp material. Thus, $\mathrm{K}_{2} \mathrm{CO}_{3}$ was found effective particularly when used at $900^{\circ} \mathrm{C}$ and the densification is $20 \%$ enhanced. Furthermore, densification ratios slightly decreased with increasing added amounts. A secondary 


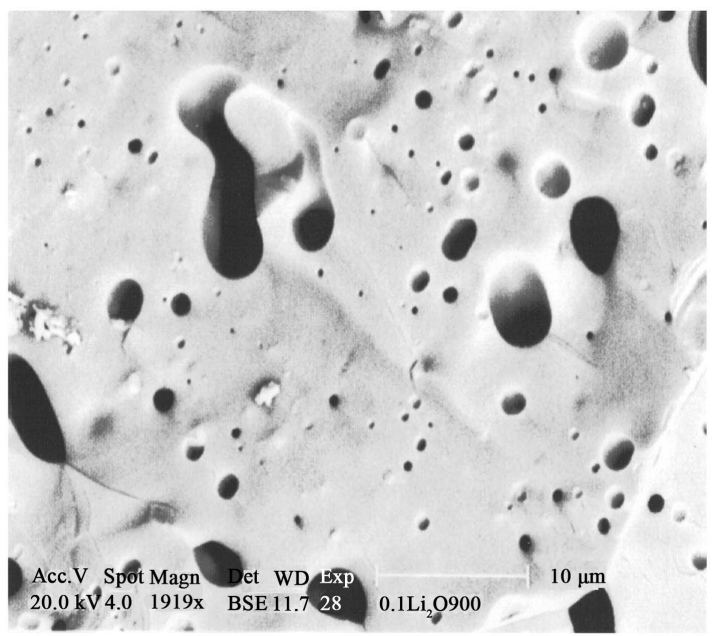

(a)

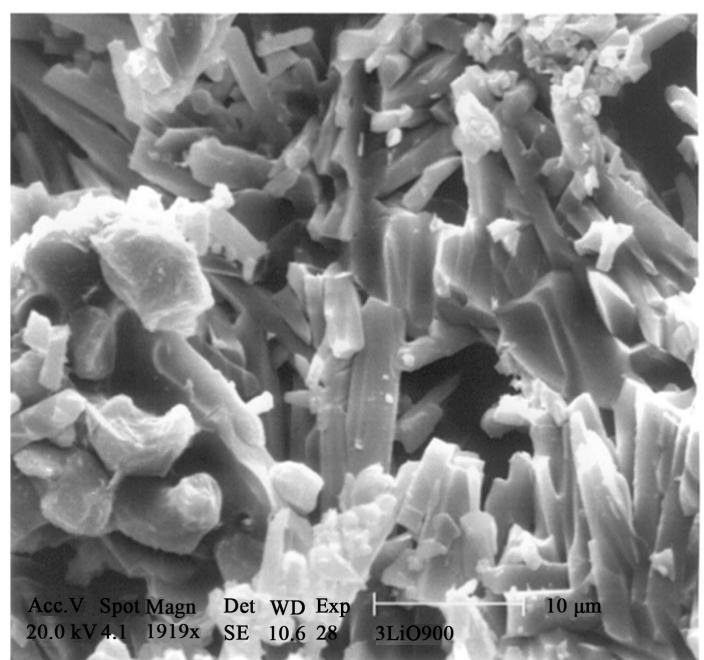

(b)

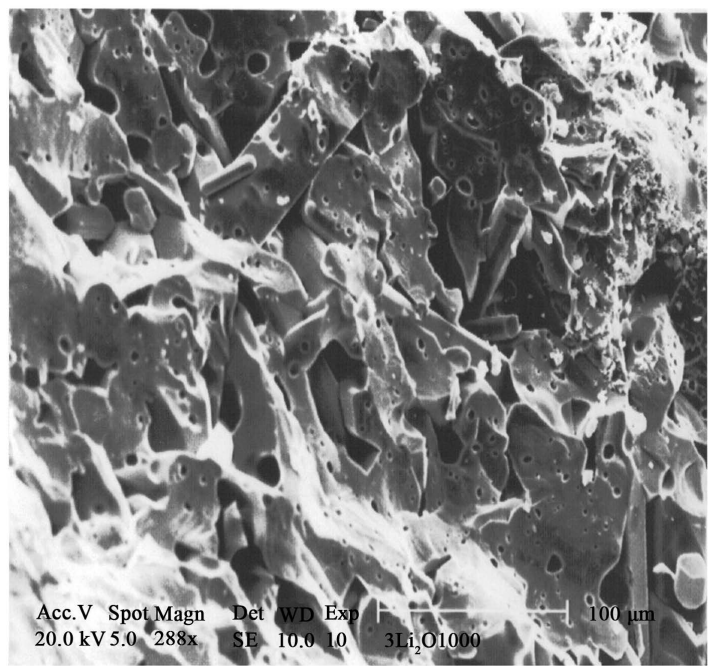

(c)

Figure 6. Scanning electron microscopy fracture micrographs of FAp sintered with $\mathrm{Li}_{2} \mathrm{CO}_{3}$. (a) $0.1 \mathrm{wt} \%$ at $900^{\circ} \mathrm{C}$; (b) $3 \mathrm{wt} \%$ at $900^{\circ} \mathrm{C}$; (c) $3 \mathrm{wt} \%$ at $1000^{\circ} \mathrm{C}$. 
phase of $\mathrm{K}_{4} \mathrm{CaPO}_{4}$ given by XRD analysis (Figure 7) and already detected with Mg-containing FAp [22], had an increasing amount with increased added $\mathrm{K}_{2} \mathrm{CO}_{3}$. This was confirmed by the important grain coarsening seen in micrographs of Figure 8. In fact, microstructure of the sample sintered with $0.1 \mathrm{wt} \%$ at $900^{\circ} \mathrm{C}$ is formed by welded grains with a slight coarsening and having an average diameter of $1 \mu \mathrm{m}$. Particles of the secondary phase $\mathrm{K}_{4} \mathrm{CaPO}_{4}$ appeared in the form of agglomerate on the fracture surface. Besides, few large pores are also present. These two facts may be responsible for the $90 \%$ densification of the material. When the additive amount increased up to $3 \mathrm{wt} \%$ still at $900^{\circ} \mathrm{C}$, the microstructure becomes heterogeneous and was formed by two types of bodies; big polyhedral grains and irregular, disordered sticks. Evidently, their presence together enhances the densification of FAp material. When temperature increased up to $1000^{\circ} \mathrm{C}$, microstructure observed with $3 \mathrm{wt} \%$ is formed by disordered and irregular sticks causing a abundant porosity in sintered bodies. As a consequence, densification ratios decreased to $88 \%$. Therefore, sintering in the presence of $\mathrm{K}_{2} \mathrm{CO}_{3}$ occurs in the liquid phase. At lower amounts, the process of grain rearrangement and dissolution-recrystallization leads to a good densification of the material. But for high amount, there is a redistribution of matter with crystallization of large sticks accompanied by an important grain coarsening, which limits the FAp densification.

\subsubsection{Alkaline-Earth Additives}

From the results gathered in Table 2, the used alkaline-earth sintering additives overall promote densification of the FAp material. At $900^{\circ} \mathrm{C}$, the densification ratios were $12 \%$ approximately enhanced compared to pure FAp. At $1000^{\circ} \mathrm{C}$, rates of about $96 \%$ were also obtained with $3 \mathrm{wt} \%$. The X-ray crystallographic analysis reveals no secondary phases except that of $\mathrm{CaO}$ formed only with $\mathrm{CaCl}_{2}$ (Figure 9).

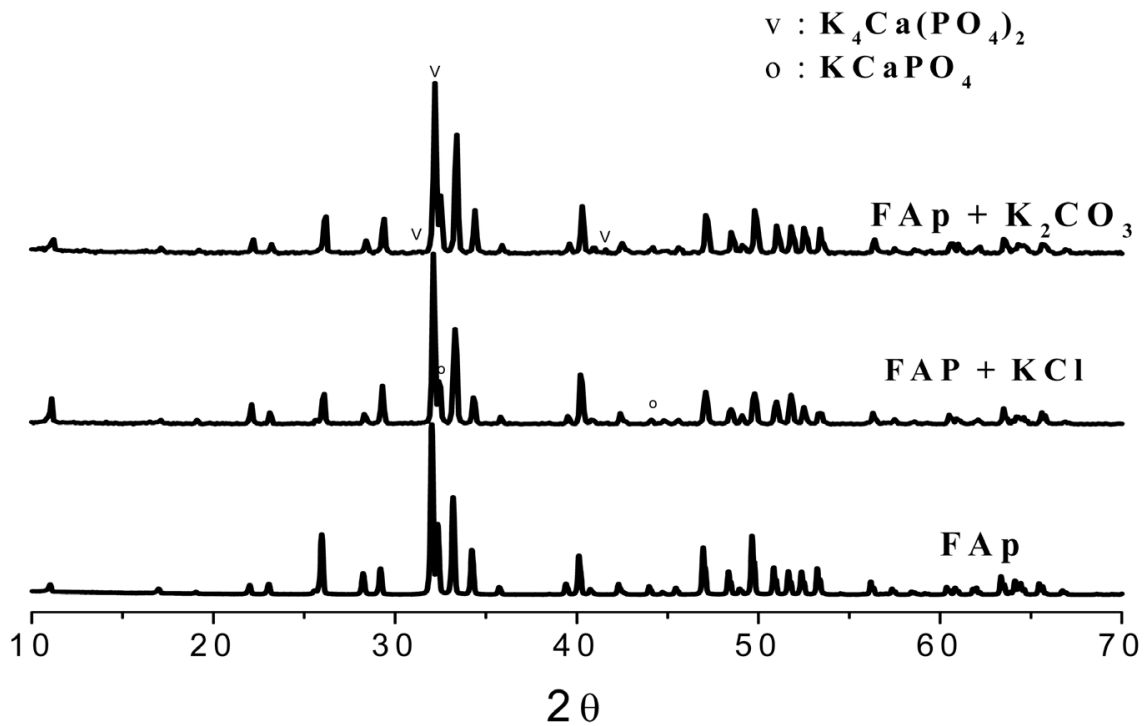

Figure 7. Diffractograms of FAp sintered with $3 \mathrm{wt} \% \mathrm{~K}_{2} \mathrm{CO}_{3}$. 


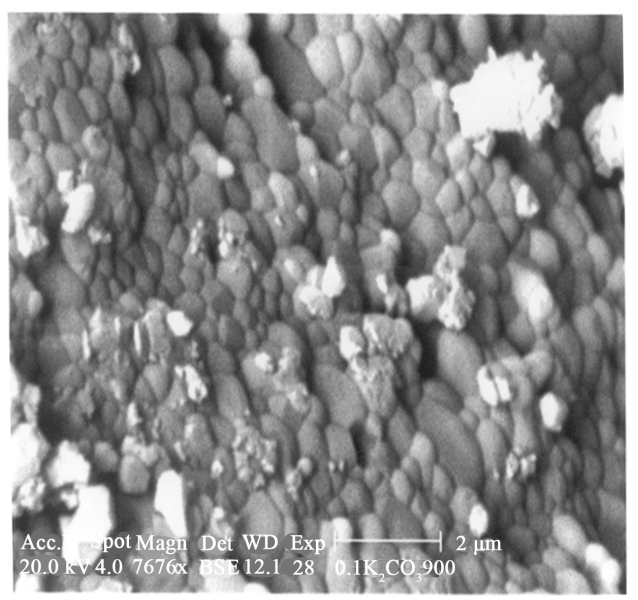

(a)

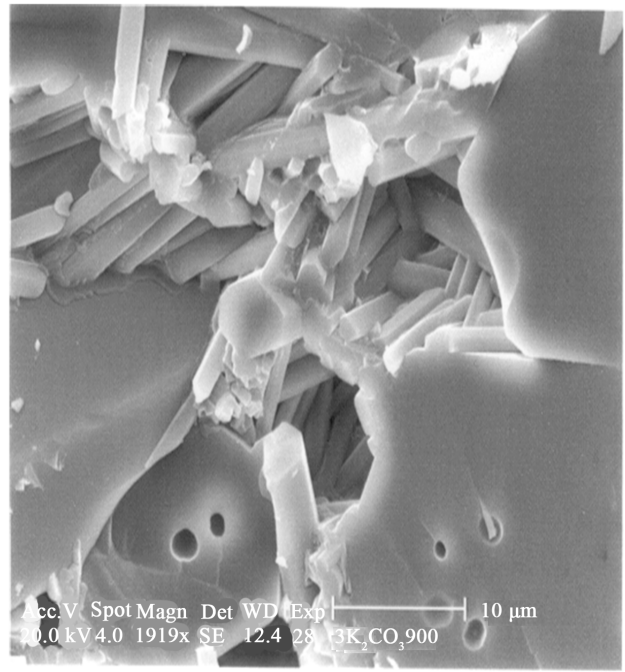

(b)

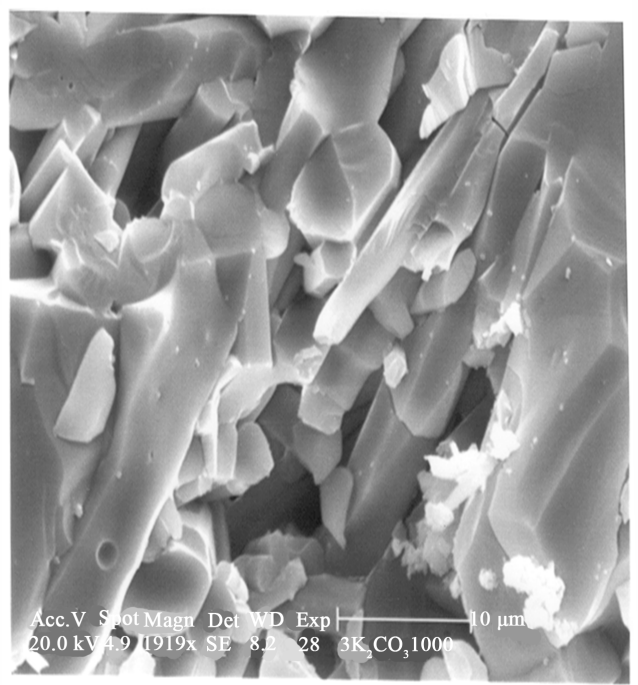

(c)

Figure 8. Scanning electron microscopy fracture micrographs of FAp sintered with $\mathrm{K}_{2} \mathrm{CO}_{3}$. (a) $0.1 \mathrm{wt} \%$ at $900^{\circ} \mathrm{C}$; (b) $3 \mathrm{wt} \%$ at $900^{\circ} \mathrm{C}$; (c) $3 \mathrm{wt} \%$ at $1000^{\circ} \mathrm{C}$. 


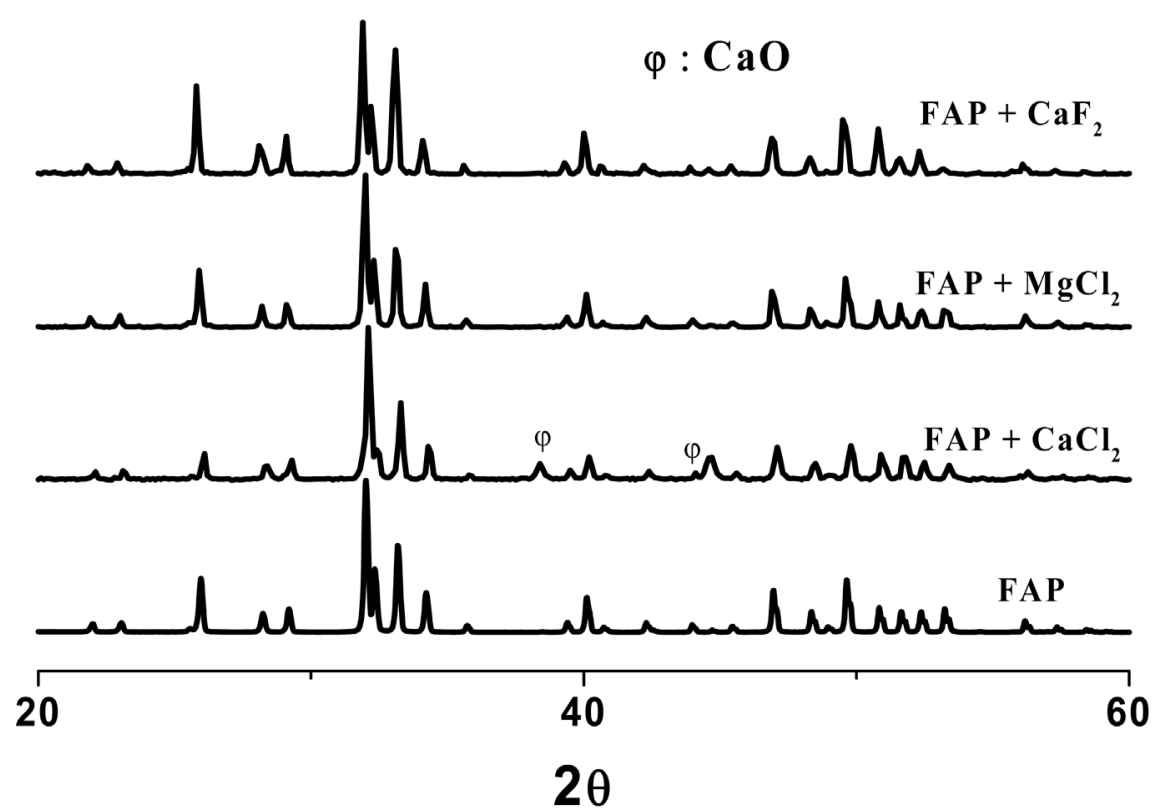

Figure 9. Diffractograms of FAp sintered with Alkaline-earth additives.

Scanning electron microscopic investigation given in Figure 10 show the morphological behavior when temperature and additive's amount varies. It was found that specimens sintered with $\mathrm{CaCl}_{2}$ and $\mathrm{MgCl}_{2}$ have a quasi similar behavior which can be explained by their nearest melting points of $772^{\circ} \mathrm{C}$ and $714^{\circ} \mathrm{C}$ respectively. Evidently, sintering occurred in the presence of a liquid phase and its kinetic varies from $900^{\circ} \mathrm{C}$ to $1000^{\circ} \mathrm{C}$ in accordance with the different given densification ratios. At $900^{\circ} \mathrm{C}$, with $3 \mathrm{wt} \%$ of $\mathrm{CaCl}_{2}$ or $\mathrm{MgCl}_{2}$, the microstructure of specimens is formed by polyhedral grains. These grains present an important grain growth and their size can exceeded $20 \mu \mathrm{m}$ which limits the material densification (Figure 10(a) and Figure 10(b)). A closed porosity formed at the surface of these polyhedral grains seems to be not completely filled by the liquid phases. Which suggest that after the grains rearrangement that of dissolution-diffusion-reprecipitation was not yet completely finished, while, when sintering temperature increased up to $1000^{\circ} \mathrm{C}$, the two microstructures took a transgranular aspect with reduced porosity (Figure 10(c) and Figure 10(d)) coherent to the obtained ratios of $96 \%$. The pores seem to be filled completely by the liquid phase and the dissolution-diffusion-reprecipitation processes was fulfilled. This is how, the steps of sintering (rearrangement-solution/precipitationdensification) are favored by the capillary forces, brought by the liquid phase, and promote the material densification. Regarding $\mathrm{CaF}_{2}$, sintering occurred in a solid phase with respect to its higher melting point $\left(1418^{\circ} \mathrm{C}\right)$. With $3 \mathrm{wt} \% \mathrm{CaF}_{2}$ at $900^{\circ} \mathrm{C}$, Figure 10 (e) shows a homogenous microstructure formed by polyhedral grains of $1 \mu \mathrm{m}$ diameter. An abundant intergranular porosity enhances the material densification. At $1000^{\circ} \mathrm{C}$, there was an important grain growth which was accompanied by the presence of some pores at the fracture surface. The sintering mechanism might be driven by the volume diffusion of atoms. 


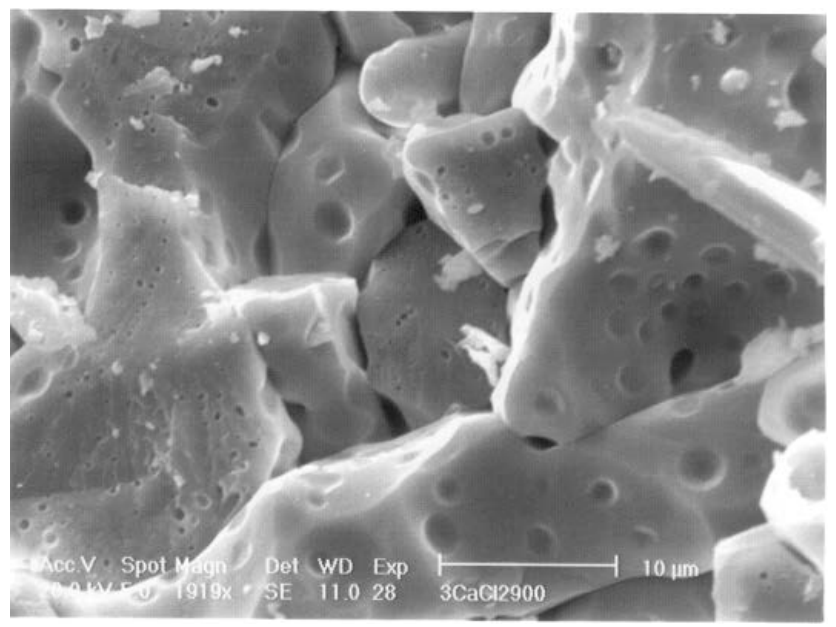

(a)

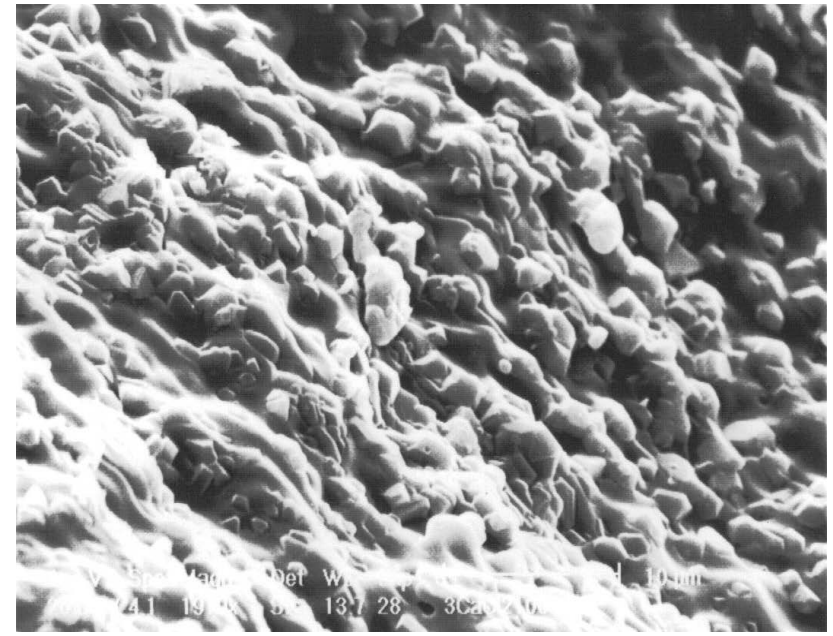

(c)

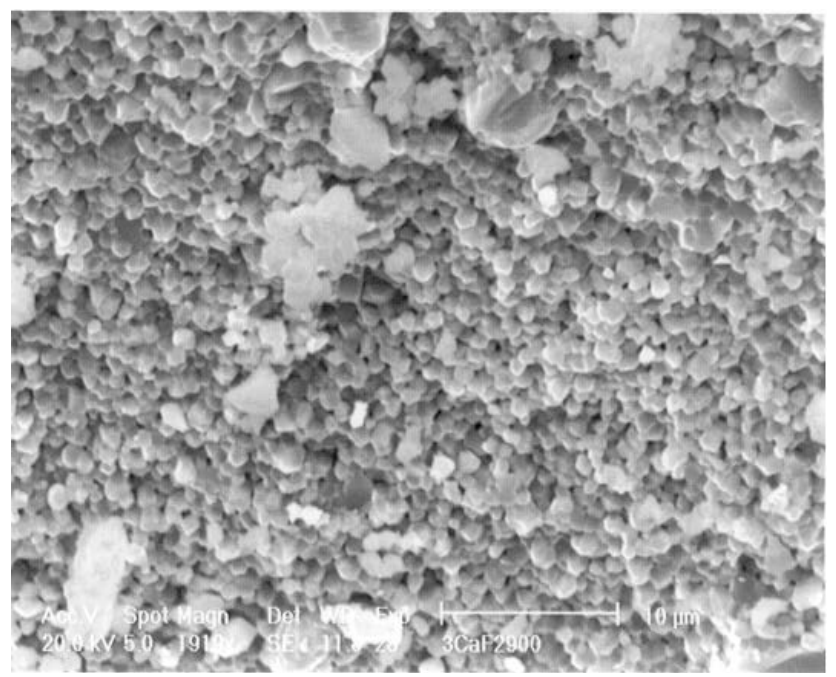

(e)

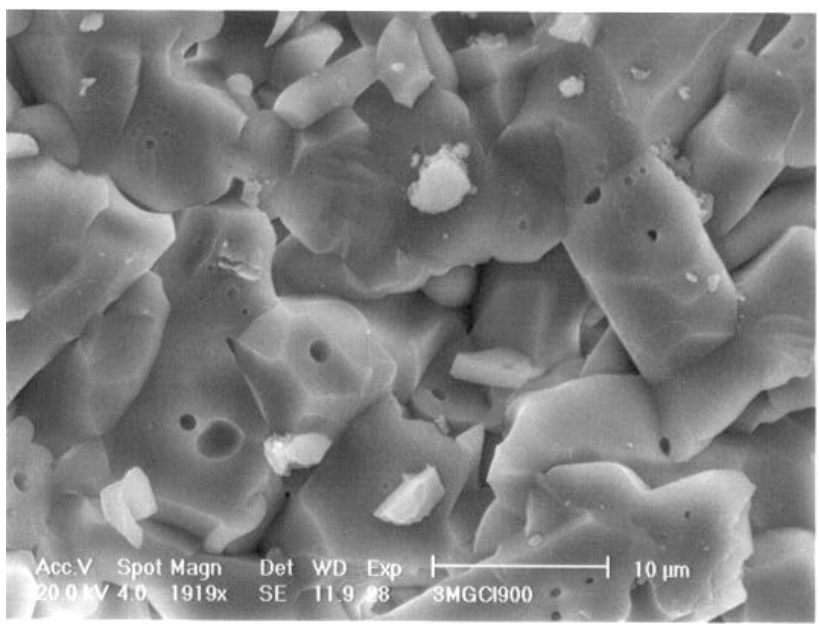

(b)

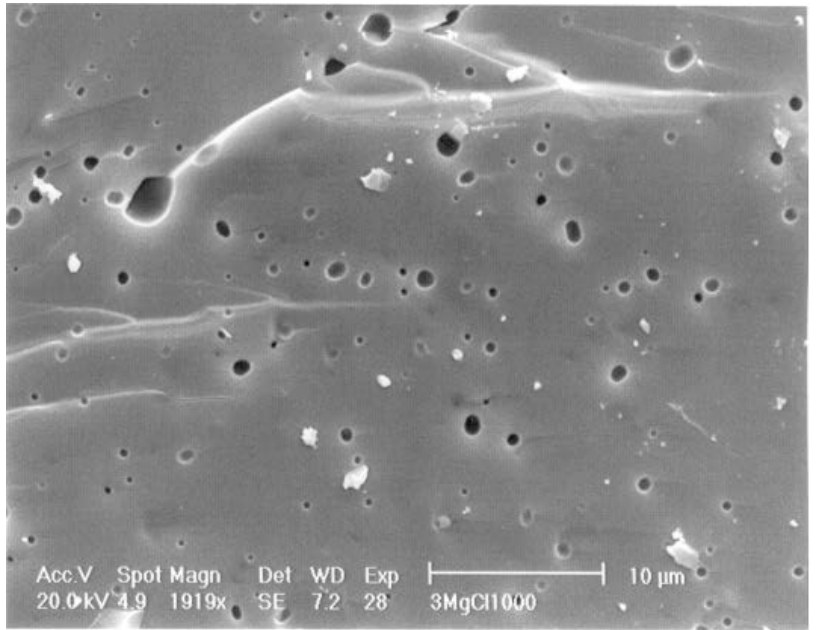

(d)

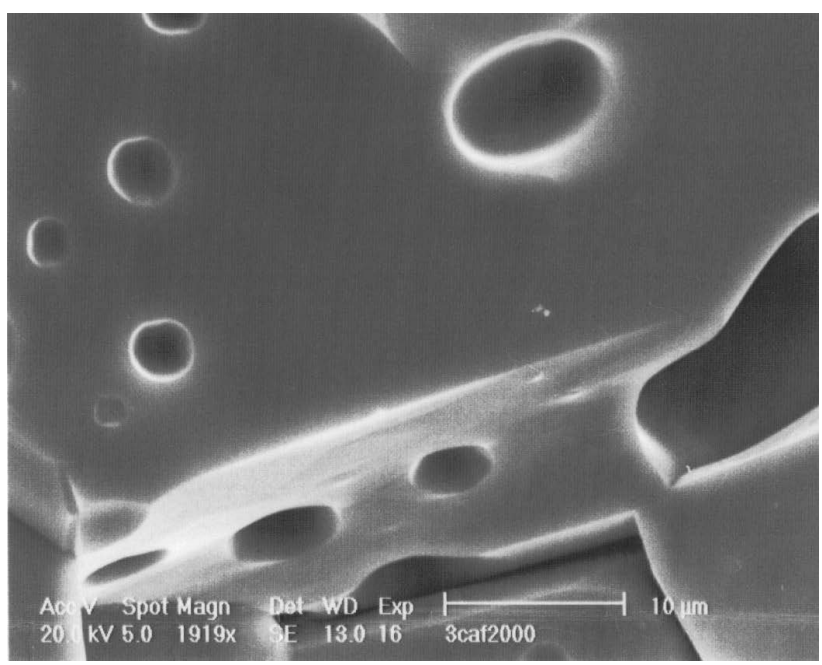

(f)

Figure 10. Scanning electron microscopy micrographs of sintered FAp with alkaline-earth sintering additives. (a) $3 \mathrm{wt} \% \mathrm{CaCl}{ }_{2}$ at $900^{\circ} \mathrm{C}$; (b) $3 \mathrm{wt} \% \mathrm{MgCl}_{2}$ at $900^{\circ} \mathrm{C}$; (c) $3 \mathrm{wt} \% \mathrm{CaCl}_{2}$ at $1000^{\circ} \mathrm{C}$; (d) $3 \mathrm{wt} \% \mathrm{MgCl}_{2}$ at $1000^{\circ} \mathrm{C}$; (e) 3 wt $\% \mathrm{CaF}_{2}$ at $900^{\circ} \mathrm{C}$; (f) 3 wt $\% \mathrm{CaF}_{2}$ at $1000^{\circ} \mathrm{C}$. 


\section{Conclusion}

In the present work, we studied the influence of some alkaline and alkaline-earth additives on the densification and microstructure of FAp. When added amounts, sintering temperatures and the duration were well adjusted, except for $\mathrm{KCl}$, all used additives improve the densification and allow obtaining densities as high as $96 \%$. The morphological investigations showed that each sintering aid leads to a particular microstructure in relationship with the additive nature as well as the densification ratios. With additives having lower than $900^{\circ} \mathrm{C}$ melting points, sintering occurs in the presence of a liquid phase and the mechanism responsible is that of rearrangement dissolution-diffusion-reprecipitation. Whereas with the other additives having higher than $1000^{\circ} \mathrm{C}$ melting points, sintering takes place at solid phase and the mechanism responsible is that of volume diffusion. In fact, sintering at $900^{\circ} \mathrm{C}$ was found efficient especially with $\mathrm{Na}_{2} \mathrm{CO}_{3}, \mathrm{NaF}, \mathrm{Li}_{2} \mathrm{CO}_{3}$ and $\mathrm{K}_{2} \mathrm{CO}_{3}$ at appropriate amounts. While, with the adequate amount, all used sintering additives were efficient at $1000^{\circ} \mathrm{C}$ and the $96 \%$ ratios were achieved.

\section{References}

[1] Magallanes-Perdomo, M., Luklinska, Z.B., De Aza, A.H., Carrodeguas, R.G., De Aza, S. and Pena, P. (2011) Bone-Like Forming Ability of Apatite-Wollastonite Glass Ceramic. European Ceramic Society, 31, 1549-1561. https://doi.org/10.1016/j.jeurceramsoc.2011.03.007

[2] Yubao, L., Klein, C.P.A.T., Xingdong, Z. and de Groot, K. (1994) Formation of a Bone Apatite-Like Layer on the Surface of Porous Hydroxyapatite Ceramics. Biomaterials, 15, 835-841. https://doi.org/10.1016/0142-9612(94)90039-6

[3] Agathopoulos, S., Tulyaganov, D.U., Marques, P.A.A.P., Ferro, M.C., Fernandes, M.H.V. and Correia, R.N. (2003) The Fluorapatite-Anorthite System in Biomedicine. Biomaterials, 24, 1317-1331. https://doi.org/10.1016/S0142-9612(02)00468-4

[4] Shadanbaz, S. and George, J.D. (2012) Calcium Phosphate Coatings on Magnesium Alloys for Biomedical Applications. Acta Biomaterialia, 8, 20-30. https://doi.org/10.1016/j.actbio.2011.10.016

[5] Al-Sanabani, J.S., Madfa, A.A. and Al-Sanabani, F.A. (2013) Application of Calcium Phosphate Materials in Dentistry. Biomaterials, 2013, Article ID: 876132. https://doi.org/10.1155/2013/876132

[6] Corno, M., Rimola, A., Bolis, V. and Ugliengo, P. (2010) Hydroxyapatite as a Key Biomaterial: Quantum-Mechanical Simulation of Its Surfaces in Interaction with Biomolecules. Physics Chemistry Physics, 12, 6309-6329. https://doi.org/10.1039/c002146f

[7] Kumar, A.R. and Kalainathan, S. (2008) Growth and Characterization of NanoCrystalline Hydroxyapatite at Physiological Conditions. Crystal Research Techno$\log$, 43, 640-644. https://doi.org/10.1002/crat.200711094

[8] Willmann, G. (1999) Coating of Implants with Hydroxyapatite-Material Connections between Bone and Metal. Advanced Engineering Materials, 1, 95-105. https://doi.org/10.1002/(SICI)1527-2648(199910)1:2<95::AID-ADEM95>3.0.CO;2$\underline{\mathrm{P}}$

[9] Sun, L., Berndt, C.C., Gross, K.A. and Kucuk, A. (2001) Material Fundamentals and Clinical Performance of Plasma-Sprayed Hydroxyapatite Coatings: A Review. Bio- 
medical Material Research, 58, 570-592. https://doi.org/10.1002/jbm.1056

[10] Orlovskii, V.P., Komlev, V.S. and Barinov, S.M. (2002) Hydroxyapatite and Hydroxyapatite-Based Ceramics. Inorganic Materials, 38, 973-984. https://doi.org/10.1023/A:1020585800572

[11] Ong, J.L. and Chan, D.C.N. (1999) Hydroxyapatites and Their Use as Coatings in Dental Implants. Biomedical Engineering, 28, 667-707.

[12] Fluorapatite (n.d.) (2008) Mosby’s Dental Dictionary. $2^{\text {nd }}$ Edition.

[13] Guo, T., Li, Y., Cao, G., Zhang, Z., Chang, S., Czajka-Jakubowska, A., Nör, J.E., Clarkson, B.H. and Liu, J. (2014) Fluorapatite-Modified Scaffold on Dental Pulp Stem Cell Mineralization. Dental Research, 93, 1290-1295. https://doi.org/10.1177/0022034514547914

[14] Bogdanov, B.I., Pashev, P.S., Hristov, J.H. and Markovska, I.G. (2009) Bioactive Fluorapatite-Containing Glass Ceramics. Ceramics International, 35, 1651-1655. https://doi.org/10.1016/j.ceramint.2008.07.021

[15] Liu, Y., Xiang, Q., Tan, Y. and Sheng, X. (2008) Nucleation and Growth of NeedleLike Fluorapatite Crystals in Bioactive Glass-Ceramics. Journal of Non-Crystalline Solids, 354, 938-944. https://doi.org/10.1016/j.jnoncrysol.2007.07.025

[16] Wu, W. and Nancollas, G.H. (1997) Kinetics of Nucleation and Crystal Growth of Hydroxyapatite and Fluorapatite on Titanium Oxide Surfaces, Colloids and Surfaces $B, 10,87-94$. https://doi.org/10.1016/S0927-7765(97)00054-4

[17] Ben Ayed, F. (2011) Elaboration and Characterization of Calcium Phosphate Biomaterial for Biomedical Applications. Biomaterials Physics and Chemistry, 18, 358374.

[18] Razavi, M., Fathi, M.H. and Meratian, M. (2010) Fabrication and Characterization of Magnesium-Fluorapatite Nanocomposite for Biomedical Applications. Material Characterization, 61, 1363-1370. https://doi.org/10.1016/j.matchar.2010.09.008

[19] Xiang, Q., Liu, Y., Sheng, X. and Dan, X. (2007) Preparation of Mica-Based GlassCeramics with Needle-Like Fluorapatite. Dentistry Materials, 23, 251-258. https://doi.org/10.1016/j.dental.2006.10.008

[20] Hill, R.G., Stamboulis, A., Law, R.V., Clifford, A., Towler, M.R. and Crowley, C. (2004) The Influence of Strontium Substitution in Fluorapatite Glasses and GlassCeramics. Non-Crystalline Solids, 336, 223-229. https://doi.org/10.1016/j.jnoncrysol.2004.02.005

[21] Hidouri, M., Bouzouita, K., Kooli, F. and Khattech, I. (2003) Thermal Behavior of Magnesium-Containing Fluorapatite. Material Chemistry and Physics, 80, 496-505. https://doi.org/10.1016/S0254-0584(02)00553-9

[22] Hidouri, M., bouzouita, K. and Fattah, N. (2005) Influence des ajouts sur la densification et la microstructure de la fluorapatite substituée au magnésium. Annales de Chimie science des materiaux, 30, 133-148. https://doi.org/10.3166/acsm.30.133-148

[23] Hidouri, M., Bouzouita, K., Aissa, A. and Debbabi, M. (2004) Étude structurale des fluorapatites contenant du magnésium ensubstitution. Comptes rendues de chimie, 7, 699-705.

[24] Hidouri, M., Boughzala, K., Lecompte, J.P. and Bouzouita, K. (2009) Sintering and Mechanical Properties of Magnesium-Containing Fluorapatite. Comptes Rendues de Physique, 10, 242-248. https://doi.org/10.1016/j.crhy.2009.04.001

[25] Ben Ayed, F., Bouaziz, J. and Bouzouita, K. (2001) Calcination and Sintering of Fluorapatite under Argon Atmosphere. Alloys and Compounds, 322, 238-245. 
https://doi.org/10.1016/S0925-8388(01)01200-2

[26] Suchanek, W., Yashima, M., Kakihana, M. and Yoshimura, M. (1997) Hydroxyapatite Ceramics with Selected Sintering Additives. Biomaterials, 18, 923-933.

https://doi.org/10.1016/S0142-9612(97)00019-7 